

BNWL-1128 UC-80 8.69

\title{
IRRADIATION SPECTRAL INFLUENCE ON DAMAGE CORRELATION
}

August 1969

\section{AEC RESEARCH \& DEVELOPMENT REPORT}

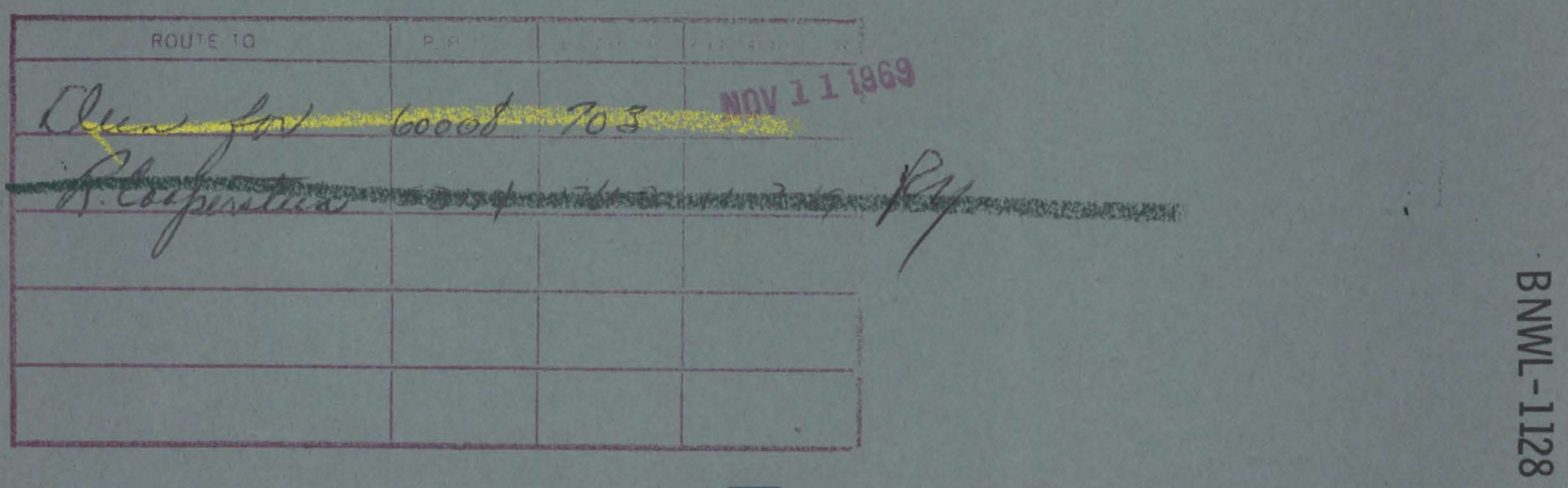

BATTELLE B NORTHWEST BATTELLE MEMORIAL INSTITUTE BATTELLE BOULEVARD. P. O. BOX 999, RICHLAND, WASHINGTON 99352 


\section{LEGAL NOTICE}

This report was prepared as an account of Government sponsored work. Neither the United Stafes, nor the Commission, nor any person acting on behalf of the Commission:

A. Makes any warranty or representation, expressed or implied, with respect to the accuracy, completeness, or usefulness of the information contained in this report, or that the use of any information, apparatus, method, or process disclosed in this report may not infringe privately owned rights; or

B. Assumes any liabilities with respect to the use of, or for damages resulting from the use of any information, apparatus, method, or process disclosed in this report.

As used in the above, "person acting on behalf of the Commission" includes any employee or contractor of the Commission, or employee of such contractor, to the extent that such employee or con. tractor of the Commission, or employee of such contractor prepares, disseminates, or provides access to, any information pursuant to his employment or contract with the Commission, or his employment with such contractor.

\section{PACIFIC NORTHWEST LABORATORY}

RICHLAND, WASHINGTON

operated by

BATTELLLE MEMORIAL INSTITUTE

for the

UNITED STATES ATOMIC ENERGY COMMISSION UNDER CONTRACT AT(45-1)-1830 
BNWL -1128

UC-80, Reactor Technology

\title{
IRRADIATION SPECTRAL INFLUENCE ON DAMAGE CORRELATION
}

\author{
By \\ G. E. Russcher \\ Metallurgy and Ceramics Department \\ Chemistry and Metallurgy Division
}

August 1969

BATTELLE MEMORIAL INSTITUTE

PACIFIC NORTHWEST LABORATORY

RICHLAND, WASHINGTON 99352 
BNWL -1128

Printed in the United States of America Available from

Clearinghouse for Federal Scientific and Technical Information National Bureau of Standards, U.S. Department of Commerce Springfield, Virginia 22151

Price: Printed Copy $\$ 3.00$; Microfiche $\$ 0.65$ 


\section{IRRADIATION SPECTRAL INFLUENCE \\ ON DAMAGE CORRELATION}

By

\section{G. E. Russcher}

\section{ABSTRACT}

An irradiation neutron spectrum plays an important role in the production of irradiation damage. This influence can be demonstrated by comparing damage calculated for the total neutron spectrum of an environment with (1) damage calculated for only the fast neutrons of the spectrum, and (2) damage calculated for a fission spectrum (often assumed equivalent to an irradiation spectrum). 


\section{TABLE OF CONTENTS}

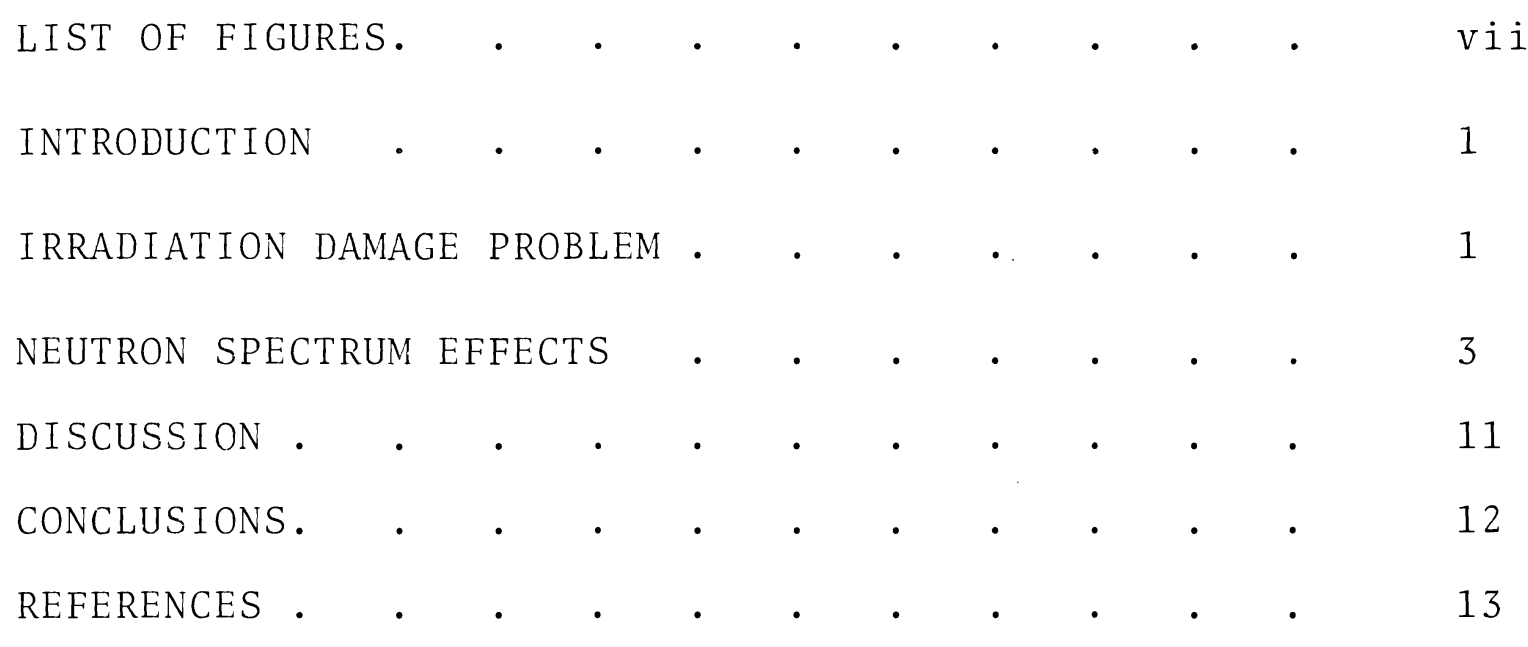




\section{LIST OF FIGURES}

1. Calculated Zirconium Displacement Production in CVTR Irradiation Facility

2. Calculated Zirconium Displacement Production in HWCTR Irradiation Facility

3. Calculated Zirconium Displacement Production in ATR Irradiation Facility

4. Calculated Zirconium Displacement Production in ETR Irradiation Facility

5. Calculated Zirconium Displacement Production in EBR-II Irradiation Facility

6. Calculated Zirconium Displacement Production in DFR Irradiation Facility 


\section{IRRADIATION SPECTRAL INFLUENCE \\ ON DAMAGE CORRELATION}

\section{G. E. Russcher}

\section{INTRODUCTION}

The neutron irradiation spectrum in a heavy water reactor is different from the spectra in other reactors. Although the response of typical dosimeters such as ${ }^{58} \mathrm{Ni}$ and ${ }^{54} \mathrm{Fe}$ to certain portions of the heavy water spectra may be quite similar to that of other reactor spectra, the resonance energy portion will differ significantly. Neutrons of these intermediate energies can produce damage in zirconium, iron, and structural materials. Hence, comparable experiments done in heavy water, light water, or fast breeder irradiation facilities may have encountered the same fast fluence as monitored by activation dosimeters. However, damage such as produced by pressure tube creep irradiation can be considerably different.

A typical and perhaps the most important structural materials problem of the heavy water-moderated reactor arises from the creep of pressure tubes within the core. The creep irradiation damage problem is presented in this report to illustrate the influence of the irradiation spectrum and the need for spectral consideration in the utilization of irradiation damage data. Significant to this problem, for example, would be how to apply a body of creep data obtained from experiment in an EBR-II test facility or ETR irradiation location to the design of a heavy water power reactor.

\section{IRRADIATION DAMAGE PROBLEM}

In-reactor creep irradiation damage can be correlated between irradiation facilities by the use of current irradiation damage computational techniques. However, two prerequisites of such a correlation are (1) selection of a damage 
mode1 relating irradiation damage production to the creep phenomena of interest, and (2) calculation, measurement, or knowledge of the neutron spectrum. After these conditions are met, defect production as defined by the model can be calculated and used as a correlation basis. The assumption is that irradiation property changes will be the same at fluences of different spectra for which equal defect production are calculated.

The structural materials problem raises the question of whether irradiation defect production can be related to observed in-reactor creep. No single damage model can describe all of the observed creep characteristics on the basis of physically sound irradiation interactions and crystal lattice behavior. In order to analyze in-reactor structural problems exhibiting creep characteristics, irradiation damage creep models relating the production of radiation-induced defects to observable creep effects are needed. Two of these are the "irradiation growth" and "yielding creep" models. Neither, however, accounts for all of the irradiation creep characteristics. These two models have also been incorporated with a "thermal creep" model into a third compound model exhibiting most of the observed creep characteristics. Even though other refinements or new models will probably be introduced, the main point of interest concerns the extent to which neutron spectra can affect conclusions based on these creep models.

In essence, the "irradiation growth" damage model attributes the expansion or growth of a crystal to radiation produced defects resulting in an accumulated internal stress. $(2,3)$ This stress is opposed by the cohesive tensile strength of the crystal. Irradiation growth can be reasonably approximated by gross displacement production within the specimen. Some defects should recombine or annihilate at the temperature of 
the creep experiment, and the remaining defects should contribute to the growth or expansion of the crystal. Thus, in the concept of "irradiation growth," irradiation defect production is identified as the cause of experimentally observed in-reactor creep for moderate creep stress. Irradiation defect production can be calculated for the neutron spectrum in each irradiation environment and used as the basis for correlation.

The "yielding creep" damage model is somewhat more complex. Plastic flow creep in this model is retarded by dislocation loops and other extended crystallographic defects produced in the lattice structure by cold work (4) or irradiation. (5) The production and behavior of moderate sized defect clusters in a lattice structure devoid of foreign atoms can be computed with existing damage simulation computer programs. Thus, the extended defect cluster concentration or production rate can be calculated for both the neutron spectrum and temperature of the irradiation environments. The results can serve as the basis of correlation for the "yielding creep" model.

If the irradiation creep data involve a range in variables requiring the compound model, the computations and creep correlation would be more complex but still possible. Both the irradiation growth and yielding creep components of that model would be influenced by the irradiation spectra.

\section{NEUTRON SPECTRUM EFFECTS}

The neutron spectrum is important to the correlation of creep since the neutron energy determines the quantity and type of lattice defects or irradiation damage that can be produced by the irradiation environment. For example, lattice atom recoil interactions and $(n, \alpha)$ helium producing interactions can predominate in one spectrum, but remain insignificant in others due to the energy dependence of the nuclear 
interaction cross sections. Both of these interactions may influence creep, but in different ways to result in different creep characteristics.

Gross displacement production can be calculated for zirconium atoms of zircalloy creep specimens to show the possible difference in damage produced in these irradiation environments. Irradiation damage was calculated using analytic functions relating displacement production to the energy of the incident neutrons. These elementary calculations do not account for material lattice structure, anisotropic neutron interactions, or the recombination of any defects. The average energy transferred during elastic collisions is used as input to the Kinchin and Pease model ${ }^{(6)}$ to calculate gross displacement production.

The purpose of these calculations was to show spectral dependence. Rather than comparing the magnitudes of these damage estimates, the zirconium damage per unit fluence is shown in Table 1 for several irradiation environments. Damage response functions representing the effectiveness of the neutrons at any energy in producing defects are illustrated in Figures 1 through 6 for severai environments. The figures illustrate that it would be misleading to consider only the damage produced by fast neutrons ( $\mathrm{E}>1 \mathrm{MeV}$ ).

\section{TABLE 1. Zirconium Displacement Production in Irradiation Facilities}

\begin{tabular}{|c|c|c|c|c|}
\hline Facility & 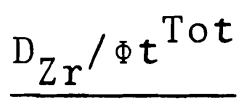 & $\mathrm{D}_{\mathrm{Zr}} / \mathrm{A}_{\mathrm{Fe}}$ & $\mathrm{D}_{\mathrm{Zr}_{\mathrm{r}}} / \Phi \mathrm{t}(\mathrm{E}>1)$ & $\mathrm{D}_{\mathrm{Zr}} / \Phi \mathrm{t}_{\text {fast }} \overline{\text { fission }}$ \\
\hline CVTR & 21 & 4.0 & 411 & 5,994 \\
\hline HWCTR & 7 & 3.9 & 468 & 15,265 \\
\hline ATR & 51 & 3.9 & 397 & 2,326 \\
\hline ETR & 45 & 4.1 & 426 & 2,630 \\
\hline EBR-I I & 179 & 7.8 & 629 & 2,111 \\
\hline DFR & 161 & 9.5 & 700 & 3,096 \\
\hline
\end{tabular}




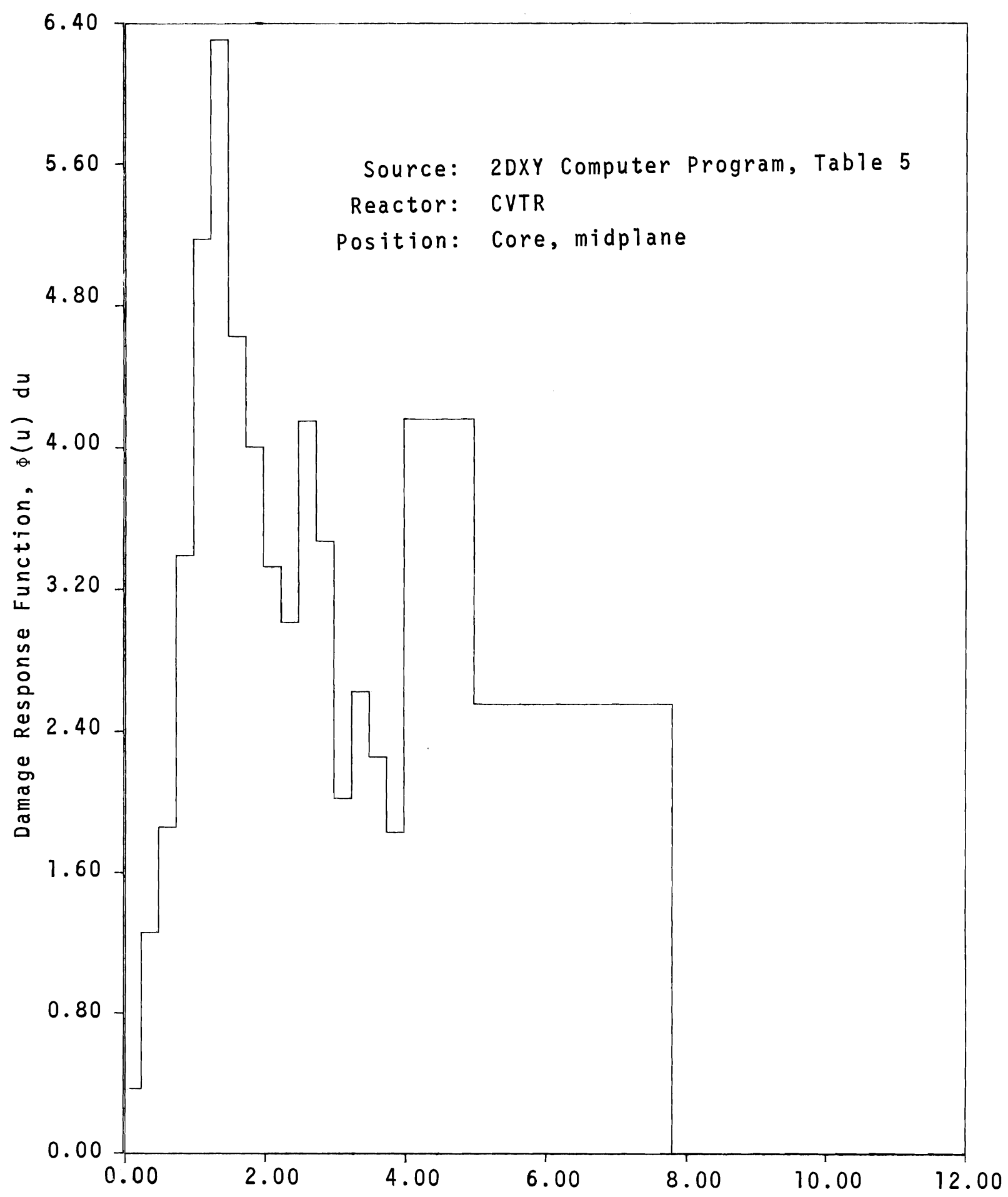

FIGURE 1. Calculated Zirconium Displacement Production in CVTR Irradiation Facility 
BNWL - 1128

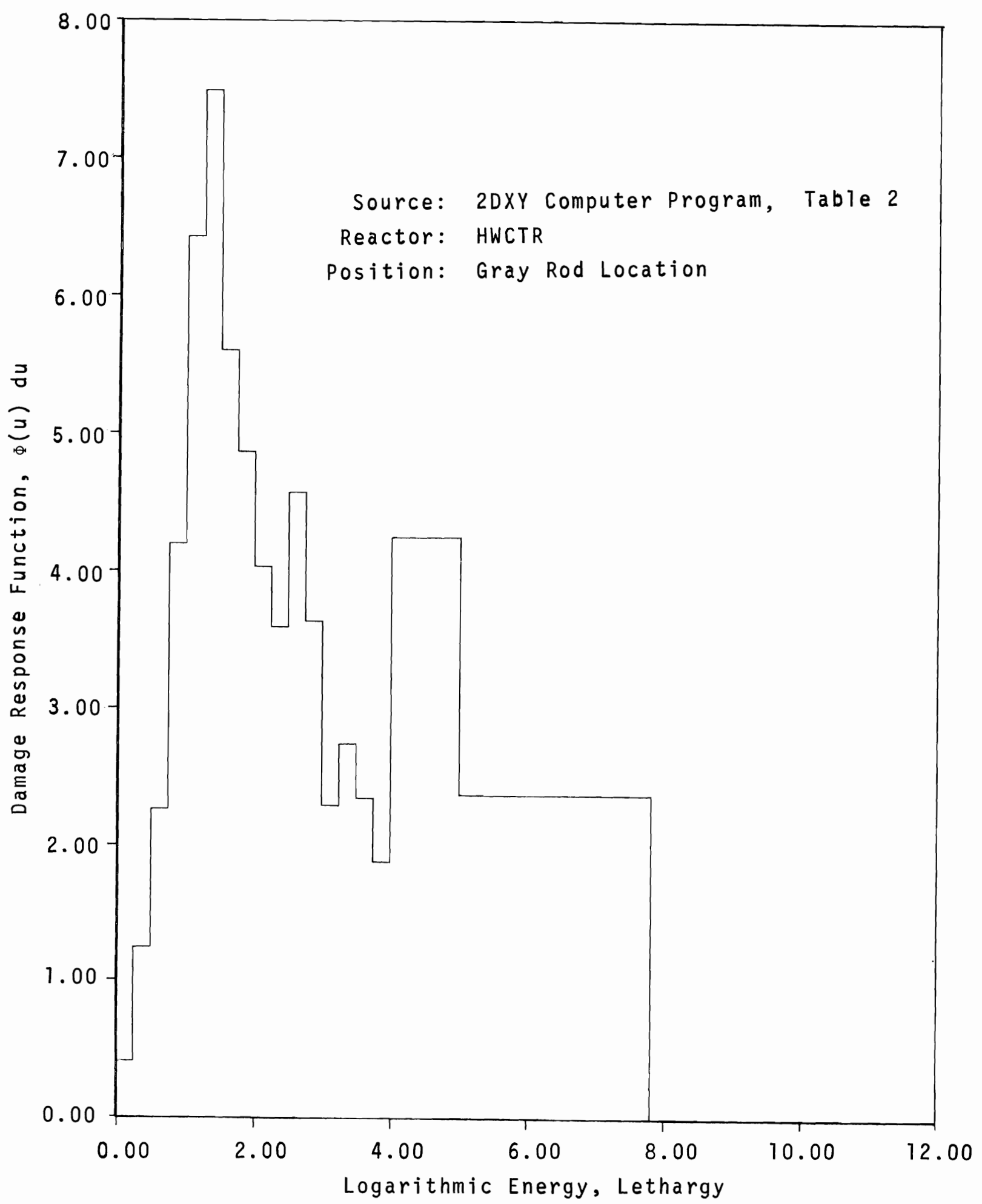

FIGURE 2. Calculated Zirconium Displacement Production in HWCTR Irradiation Facility 


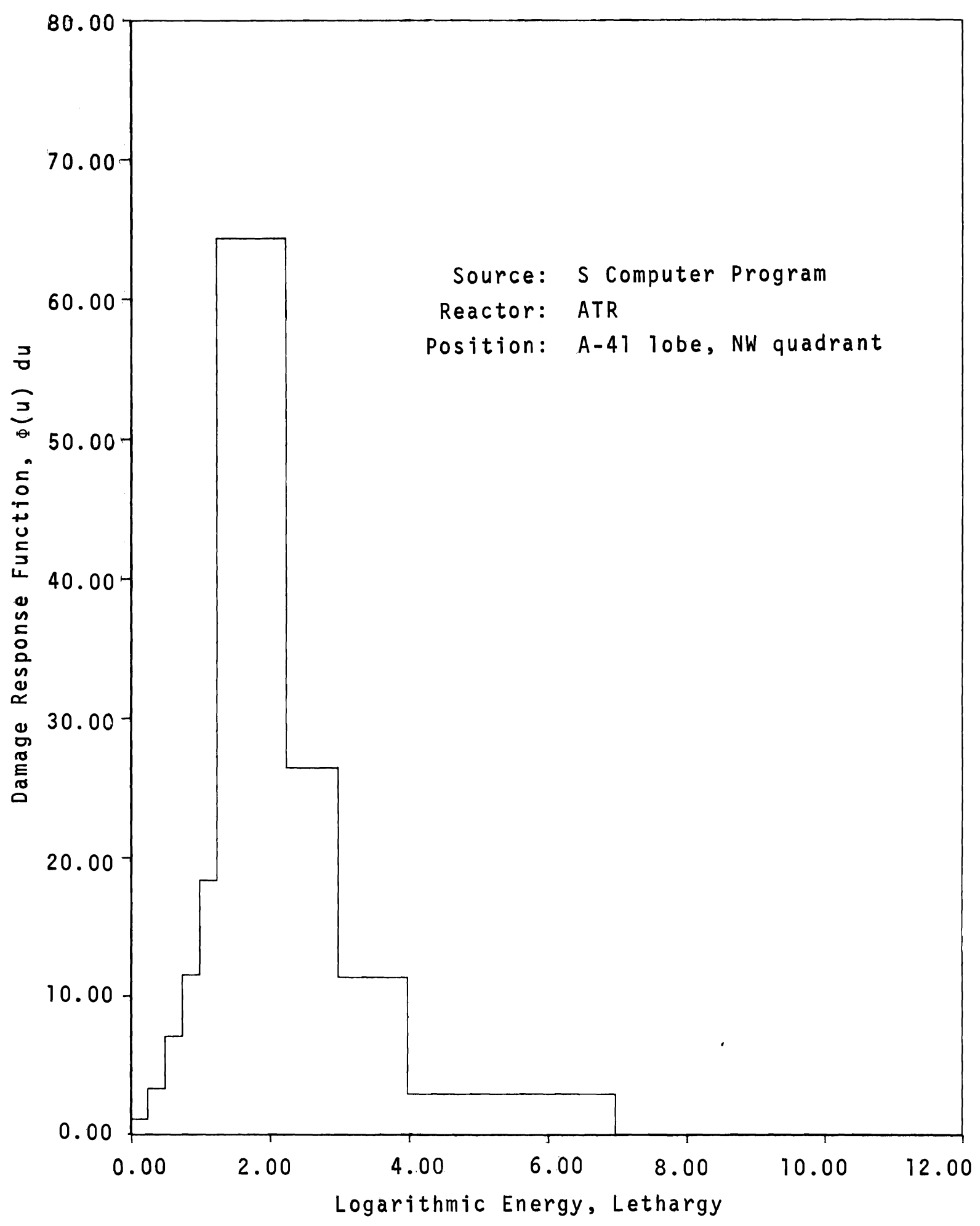

FIGURE 3. Calculated Zirconium Displacement Production in ATR Irradiation Facility 


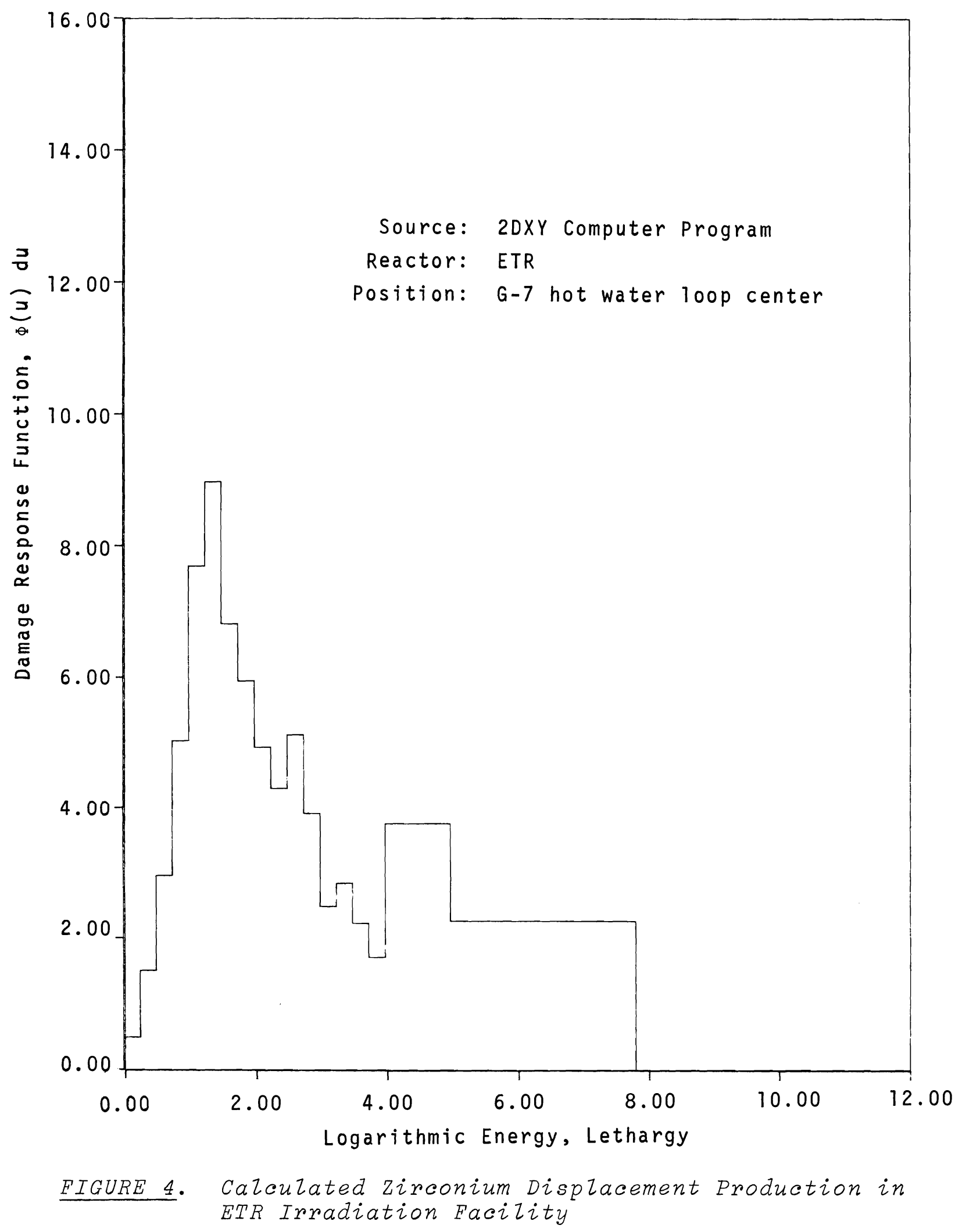




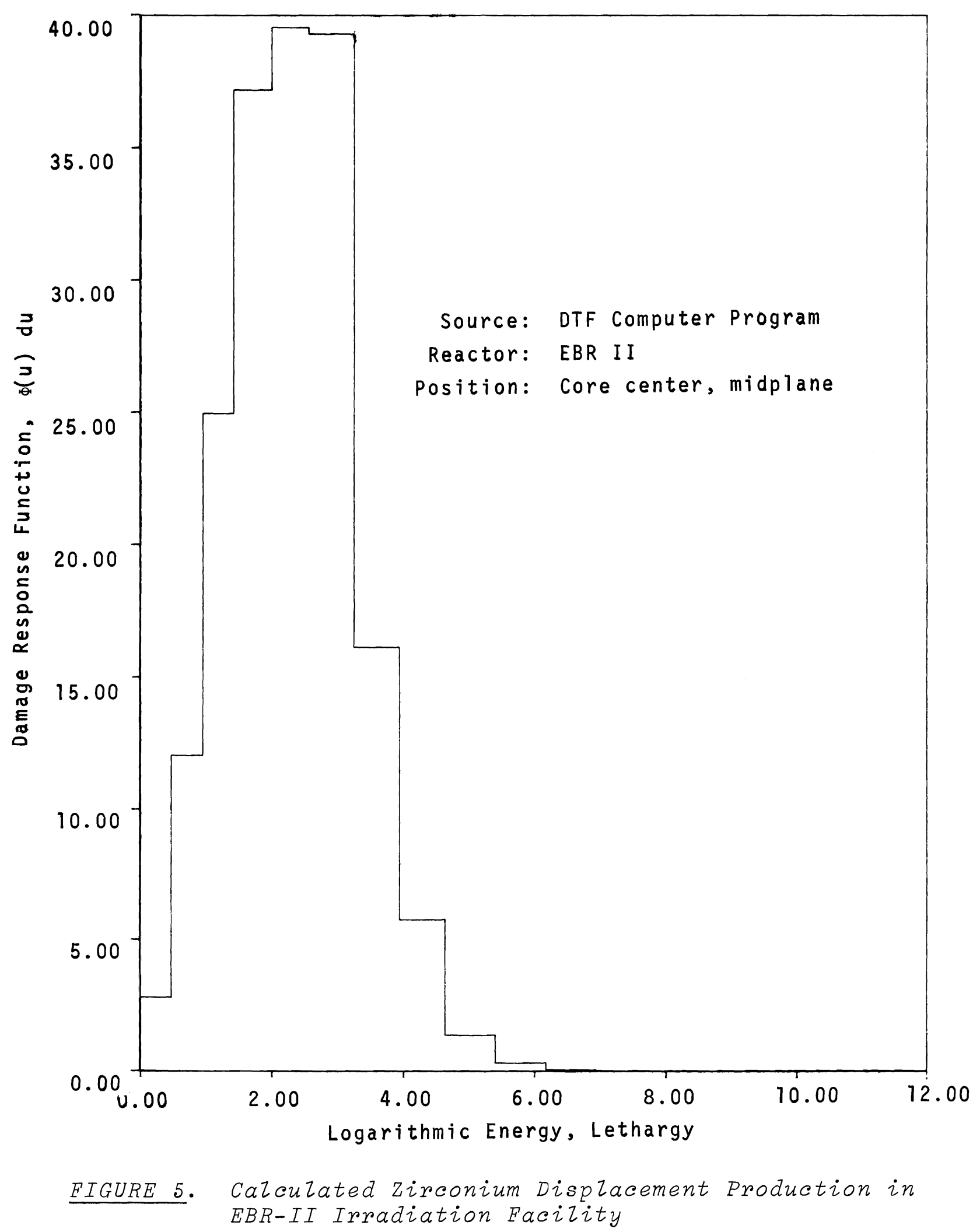




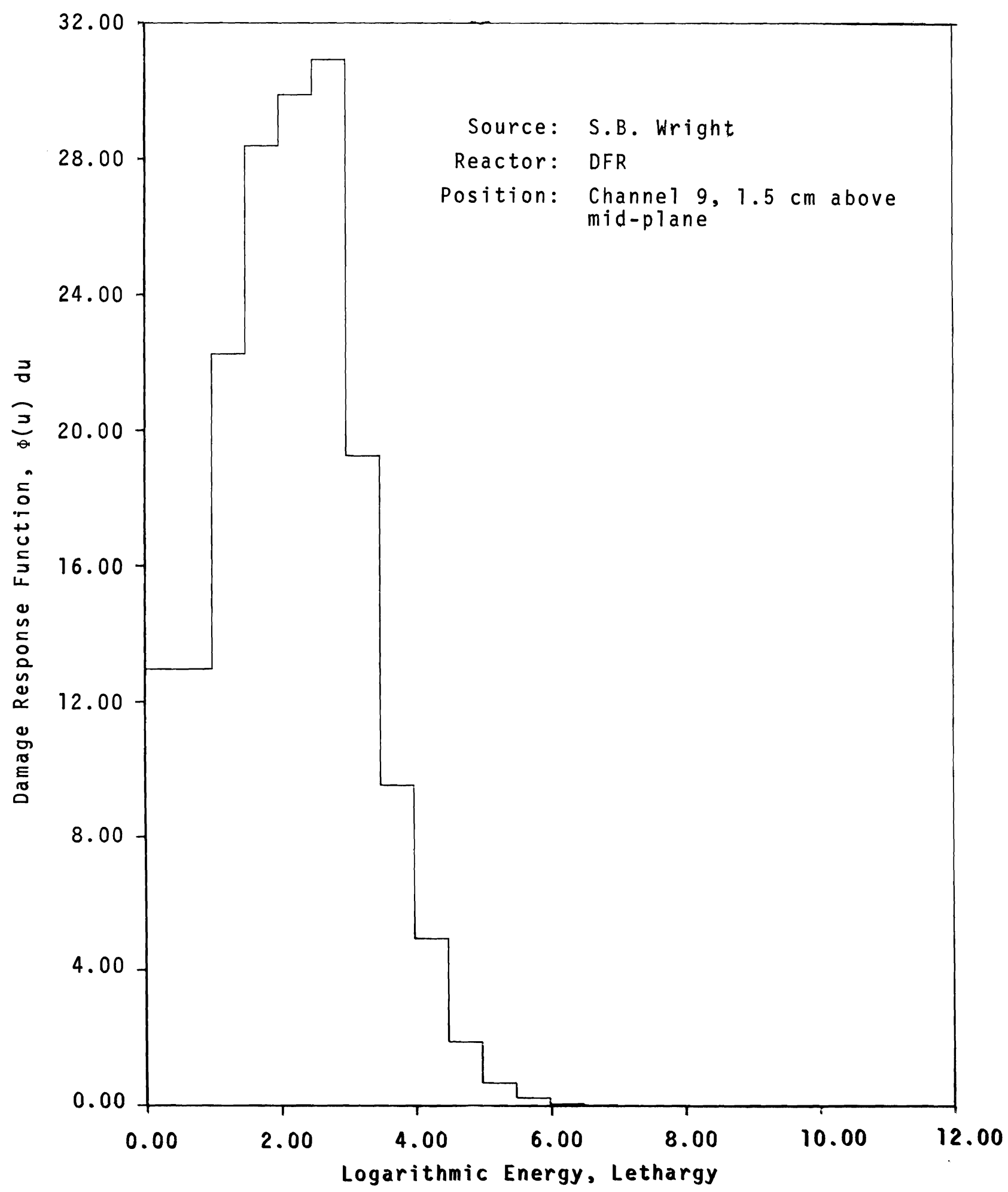

FIGURE 6. Calculated Zirconium Displacement Production in DFR Irradiation Facility 
While nickel and iron are common fast neutron activation dosimeters, they do not monitor irradiation damage. Two irradiations producing the same iron activation may not produce the same damage, as illustrated in Table 1 by the ratio of displacement production in zirconium to iron activation $\mathrm{D}_{\mathrm{Zr}} / \mathrm{A}_{\mathrm{Fe}}$. As previously reported, (7) some reactors have the same ratio of zirconium damage to dosimeter activation. Such is the case among the first four reactors of Table 1 . However, fast reactors do not have that same ratio.

The relation of displacement production to the fast fluences ( $\mathrm{E}>\mathrm{MeV}$ ) in each of the environments is also shown. Displacement production per unit fluence ( $\mathrm{E}>1 \mathrm{MeV}$ ) shows substantial variation among the reactors. Thus, the direct application of EBR-II creep data per unit fluence ( $>1 \mathrm{MeV}$ ) to a HWCTR problem could implicitly include an error of $34 \%$.

\section{DISCUSSION}

When irradiation spectral data are not available, the property changes in experimental materials are often related by a fission spectrum-averaged cross section for the activation dosimeter. In effect, this approach assumes the irradiation environment to possess a fission neutron spectrum. The inaccuracy of using fission spectrum-averaged cross sections for the dosimetry of irradiation damage experiments is also illustrated in Table 1. A comparison of the displacements per unit fission spectrum-averaged fluence $\mathrm{D}_{\mathrm{Zr}} /(\Phi t$ fast $\overline{\text { fission) }}$, among the various reactors, or with the damage per unit total fluence based on iron activation, shows very different ratios. The direct application of data assuming a fission spectrum in all facilities could include errors of a factor of seven when correlating data between the EBR-II and HWCTR.

Calculated displacement production is not proportional to fast fluence or even to total fluence in irradiation facilities. 
The ratio of zirconium damage to iron activation is consistent for some, but not all irradiation facilities. Because use of the unit "fast fission averaged fluence" as shown in Table 1 could include the errors of nearly an order of magnitude, the neutron spectrum of the irradiation location is concluded to be essential to the correlation of creep data.

In-reactor creep experiments should be documented with the following technical detail: (1) irradiation neutron spectrum measurement, (2) Complete metallurgical description and history, and (3) Accurate measurement of such experimental parameters as temperature, creep, stress, creep strain, and strain rate.

\section{CONCLUSIONS}

- The irradiation neutron energy spectrum is found to be a dominant factor in the production of materials irradiation damage such as in-reactor creep. Maximum utilization of experimental creep data demands that this spectrum be known.

- At least three irradiation damage creep models and several available techniques might be used to correlate creep data. A study is suggested to establish their validity for that purpose. 


\section{REFERENCES}

1. F. A. Nichols. "Theory of the Creep of Zircaloy During Neutron Irradiation," J. Nucl. Mater., vol. 30, pp. 249-270. 1969 .

2. G. R. Piercy. "Mechanisms for the In-Reactor Creep of Zirconium AZloys," J. Nucl. Mater., vol. 26, pp. 18-50. 1968 .

3. A. C. Roberts and A. H. CottrelZ. "Radiation Growth in a Uranium," Phil. Mag., vol. 1, p. 711. 1956.

4. C. E. EZZis and V. FidZeris. "Effect of Neutron Irradiation on Tensile Properties of the Zirconium-2. 5 Weight Per Cent Niobium AZloy," Electrochemical Technology, vol. 4, no. 5-6, pp. 268-274. May-June 1966.

5. R. V. Hesketh. "Application of the Generalized Theory of Yielding Creep to Irradiation Creep in Zirconium AlZoys," J. Nucl. Mater., vol. 26, pp. 77-86. 1968.

6. G. H. Kinchin and R. S. Pease. "The Displacement of Atoms in Solids by Radiation," Rep. Prog. Phys., vol. 18, p. 1-51. 1955 .

7. G. R. Piercy. "The Effect of the Fast Neutron Spectrum on the Rate and Distribution of Damage in Zirconium," J. Nucl. Mater., vol. 29, pp. 267-284. 1969. 
BNWL -1128

\section{DISTRIBUTION}

No. of

Copies

OFFSITE

AEC Chicago Patent Group

G. H. Lee

AEC Division of Reactor Development and Technology

M. Shaw, RDT Director

A. Giambusso, Asst. Director, Project Management

A. N. Tardiff, Chief, HWR Branch (2)

W. A. Williams, Jr., Chief, Desalting Branch

M. A. Rosen, Asst. Director, Plant Engineering

R. Feit (Act.), Chief, Instrument and Control Branch

E. E. Sinclair, Asst. Director, Reactor Engineering

E. E. Kintner (Act.), Chief, Core Design Branch

E. E. Kintner (Act.), Chief, Fuel Fabrication Branch

E. E. Sinclair, Asst. Director, Reactor Technology

J. M. Simmons, Chief, Fuels and Materials Branch

N. Grossman, Chief, Special Technology Branch

I. F. Zartman, Chief, Reactor Physics Branch

J. A. Lieberman, Asst. Director, Nuclear Safety

A. J. Pressesky, Chief, Analysis and Evaluation Branch

M. J. Whitman, Asst. Director, Program Analysis

H. J. Reynolds, Heavy Water Reactors Branch

218 AEC Division of Technical Information Extension

$4 \quad$ AEC RDT Site Representatives

Atomics International

Combustion Engineering

Idaho Operations Office

Oak Ridge National Laboratory

Atomic Energy of Canada, Ltd.

Toronto, Ontario, Canada

A. R. Bancroft

H. K. Rae

Center for Nuclear Studies

Department of Physical Chemistry, C.E.A., Saclay, France

E. Roth

Distr-1 
No. of

Copies

OFFSITE

1

du Pont Company, Wilmington

D. Babcock

1

Institut fur Kernverfahrentechnik

Karlsruhe, Federal Republic of Germany

E. W. Becker

1 International Atomic Energy Agency

Vienna, Austria

2 Massachusetts Institute of Technology, Lexington

E. A. Mason

$1 \quad$ USAEC Scientific Representative

c/o Atomic Energy of Canada, Ltd.

Chalk River, Ontario, Canada

R. W. Ramsey

\section{ONSITE-HANFORD}

1

AEC Chicago Patent Group

R. K. Sharp (Richland)

2

AEC RDT Site Representative (PNL)

P. G. Holsted

AEC Richland Operations Office

C. L. Robinson

Battelle Memorial Institute

3 Douglas United Nuclear, Inc.

DUN Files

48

Battelle Northwest

J. A. Ayres

J. M. Batch

S. H. Bush

R. F. Corlett

D. R. de Halas

R. L. Dillon

E. A. Eschbach

J. C. Fox

R. E. Gilbert 


\section{No. of \\ Copies}

\section{ONSITE-HANFORD}

\section{Battelle Northwest (contd)}

R. S. Hammond

H. Harty (2)

W. J. Helm

J. E. Irvin

J. N. Judy

B. B. Lane

G. A. Last

W. R. Lewis

R. P. Marshall

R. E. Nightingale

P. G. Parr

A. M. Platt

W. W. Porath

W. D. Richmond

G. E. Russcher (10)

G. A. Sawyer

L. C. Schmid

D. H. Stewart

H. A. Taylor

W. C. Wolkenhauer

H. H. Yoshikawa

J. R. Young Technical Information (5)

Technical Publications (2) 